\title{
Brazilian sugarcane agro-industry human resources' management: strategies to increase work intensity
}

\author{
A gestão de recursos humanos no complexo agroindustrial \\ canavieiro brasileiro: estratégias para aumentar a intensidade do \\ trabalho \\ Leonardo Ferreira Reis ${ }^{1}$ [1], Francisco José da Costa Alves² [0] \\ ${ }^{1}$ Universidade Federal de Itajubá - UNIFEI, Instituto de Ciências Puras e Aplicadas, Engenharia de Saúde e \\ Segurança, Itabira, MG, Brasil. E-mail: leofreis@unifei.edu.br \\ ${ }^{2}$ Universidade Federal de São Carlos - UFSCar, Centro de Ciências Exatas e de Tecnologia, Departamento de \\ Engenharia de Produção, São Carlos, SP, Brasil. E-mail: chiquinho@dep.ufscar.br
}

How to cite: Reis, L. F. \& Alves, F. J. C. (2020). Brazilian sugarcane agro-industry human resources' management: strategies to increase work intensity. Gestão \& Produção, $27(2)$, e5147.

https://doi.org/10.1590/0104-530X5147-20

\begin{abstract}
The sugarcane agro-industry complex of São Paulo State, Brazil, has undergone significant technical and organizational changes over the last two decades. The harvest mechanization process increased the work productivity and reduced drastically the workforce employed in the sector, requiring modern human resources practices to manage work in this new technical basis. The objective of this study is to analyse how the São Paulo state sugarcane complex human resources management (HRM) practices can increase the work intensity in agricultural production. The primary data of this study was obtained with a questionnaire applied to $38 \mathrm{HR}$ managers of sugarcane companies and with 18 semi-structured interviews to the sector workers and managers. The payment based on production is a traditional HRM strategy in the sector to increase productivity, and its efficiency is conditioned to the capacity of the managers to recruit and control the workforce. Therefore, in this article, the analysis focused on payment, recruitment and training programmes. Data analysis indicate that, generally, the HRM practices logic is to reward workers with higher productivity levels and punish those who flee from behavior patterns and commit deviations of quality. Even so, the heterogeneity HRM structure in sugarcane agro-industry is evident, since companies with different types of management have specific priorities. The central conclusion is that the work intensification still can be an issue in sugarcane agro-industrial complex as the variable remuneration is used to punish and reward workers based on quality and productivity indicators. The effects of this intensification process for machine operators health must be analyzed in further researches.
\end{abstract}

Keywords: Human resources management; Agricultural HRM; Working conditions; Payment based on production; Variable remuneration; Work intensification process.

Resumo: O complexo agroindustrial canavieiro do Estado de São Paulo, Brasil passou por mudanças técnicas e organizacionais significativas nas duas últimas décadas. O processo de mecanização da colheita aumentou a produtividade do trabalho e reduziu drasticamente a força de trabalho empregada no setor, exigindo modernas práticas de recursos humanos para gerir o

Received Nov. 27, 2018 - Accepted Apr. 02, 2019

Financial support: Bolsa de doutorado da Coordenação de Aperfeiçoamento de Pessoal de Nível Superior (CAPES) 
trabalho nesta nova base técnica. O objetivo deste estudo é analisar como as estratégias da gestão de recursos humanos $(\mathrm{GRH})$ do complexo canavieiro paulista são utilizadas para aumentar a intensidade do trabalho na produção agrícola do setor. Os dados primários deste estudo foram obtidos com a aplicação de um questionário a 38 gestores de $\mathrm{RH}$ de empresas canavieiras e com 18 entrevistas semiestruturadas aos trabalhadores e gestores do setor. O pagamento baseado na produção é uma estratégia tradicional de gestão de recursos humanos para aumentar a produtividade, e sua eficiência está condicionada à capacidade dos gerentes em recrutar e controlar a força de trabalho. Portanto, a análise deste estudo concentrou-se em programas de pagamento, recrutamento e treinamento de trabalhadores. A análise dos dados indica que, geralmente, a lógica das práticas de GRH é recompensar os trabalhadores com maiores níveis de produtividade e punir aqueles que fogem ao padrão de comportamento e cometem desvios de qualidade. Mesmo assim, a heterogeneidade da estrutura da GRH na agroindústria canavieira é evidente, uma vez que empresas com diferentes tipos de gestão possuem prioridades específicas. A conclusão central desse estudo é que a intensificação do trabalho ainda pode ser um problema no complexo agroindustrial canavieiro, já que a remuneração variável é utilizada como forma de punição e recompensa dos trabalhadores, tendo como base indicadores de qualidade e produtividade. Os efeitos deste processo de intensificação para a saúde operadores de máquinas devem ser analisados em pesquisas posteriores.

Palavras-chave: Gestão de recursos humanos; Agricultura; Condições de trabalho; Pagamento por produção; Remuneração variável; Processo de intensificação do trabalho.

\section{Introduction}

The sugarcane agro-industrial complex (AIC) of the São Paulo state, Brazil, is a privileged object of study due to its world importance in the production of sugar and ethanol (Baccarin, 2017; Pitta \& Mendonça, 2010). Additionally, the complex's importance has increased every year since it underwent a modernization process throughout the decades of 2000 and early 2010, modifying its technical base (Fredo et al., 2015). Despite this, few researchers in Brazil (Mundo Neto, 2013; Scopinho, 2000; Souza, 2011) and abroad (Narendra \& Bhor, 2014) have dedicated their studies to the implications of this process for the Human Resources Management $(H R M)$ in the sugarcane agro-industry, or even in agriculture generally.

The recent period of expansion and modernization of São Paulo state's sugarcane production is marked, in structural perspective, by the maintenance of high government investments, the impacts of world economic crises, and the participation of foreign companies, increasing the capital concentration in the sector (Pitta \& Mendonça, 2010; Ramos, 2011).

From an organizational and technical perspective, this modernization process changed the sugarcane production management (Souza, 2011), and accelerated the harvesting mechanization, which accounted the harvested area for $80 \%$ in the 2012/2013 cycle (Fredo et al., 2015), replacing 59\% of the manual workforce from 2007 to 2014 (Reis, 2017). The 2000's and 2010's harvest mechanization process was encouraged by environmentalist political pressure against sugarcane crop burning (Aguiar et al., 2011; Silva \& Martins, 2010), and social movements denouncing precarious working conditions in manual cutting (Alves, 2006; Silva, 2013; Silva \& Martins, 2010; Vilela et al., 2015).

The harvest mechanization process was, and still is, seen as the solution to social and environmental impacts of the São Paulo state sugarcane production (Goldemberg, 2007; Moraes et al., 2015). It changed sugarcane production's technical basis, requiring modern HRM strategies to manage the large number of harvester machine 
operators recently employed and the significant number of manual workers who still support the mechanical activities (Reis \& Alves, 2015). However, some researchers are questioning this discourse as their findings show that health problems are still present in harvester operators and other workers who still perform manual activities in sugarcane production (Reis, 2017; Scopinho et al., 1999; Silva et al., 2014).

Many social and technical factors, even the HRM practices, can be related to these health problems, as they may intensify labours' physical and mental energy levels due to increasing productivity but reducing the workers regulation space, creating conditions to increase accidents and illness levels in a process called work intensification (Gollac \& Volkoff, 1996; Dal Rosso, 2008). In sugarcane production, this problem is historically related to manual cutters, which dies from exhaustion after a hard working day exposed to inclement weather and a deadly labour rhythm (Alves, 2006; Verçosa, 2018; Vilela et al., 2015).

In mechanized operations, now predominant in all stages of the sugarcane production process (Fredo et al., 2015), the pursuit of increased labour productivity is required as more capital is invested in production, demanding a profitable return to the capital immobilized in the acquired machines. It also requires managers to find different ways to increase operators' commitment to the machines conservation and maintenance, thus accumulating tasks that requires greater physical and mental energy to be spent in work process.

Some organizational mechanisms are used to achieve the machines' economic viability requirements, such as the shift system, which allows production day and night (Silva et al., 2011). Other technological innovations are used to achieve these objectives, such as the on-board computers, which provide real-time information for managers about the machinery's functioning, with the objective, in the sugarcane sector, being to maintain workers under surveillance. Therefore, the new work process technical structure in sugarcane production, based on machine predominance, needs managerial practices to increase constantly workers individual productivity. This necessity is motivated by the fact that while each machine has a limit in its productive potential, humans can always create new ways to make their job with better efficiency (Dejours, 2005).

Therefore, this study objective is to analyse how the Sao Paulo state sugarcane complex HRM strategies are used to increase the work productivity in agricultural production after the harvest mechanization process.

The article is structured in five topics, including this introduction, where the modernization process is contextualized. In the second topic the last scientific findings on this study subject are presented, discussing the payment, recruitment and training strategies of HR managers in the sugarcane production. The next topic is dedicated to the method description. The results are discussed in the fourth topic, called Human Resources Management Strategies, where workers payment, recruitment and training practices are discussed based on research findings. Finally, in the last topic, the main conclusions are presented and some further research suggestions are proposed.

\section{Theoretical foundation}

Although there are many studies about the HR strategies used to manage sugarcane manual cutters (Alves, 2006; Cover, 2011; Menezes et al., 2012; Novaes \& Alves, 2007; Silva, 2013; Verçosa, 2018; Vilela et al., 2015), few studies are directed to understand management practices used in harvester operators (Scopinho et al., 
1999; Salata, 2013; Silva et al., 2014), the focus of the present study. In this sense, it is possible to remark three main HRM strategies to analyse as reference in the sugarcane complex, the payment method, the profile searched in recruitment and the behavioural/technical competences acquired in training programs.

Among all HRM practices, payment based on production holds the most important position in our analysis, because in it appearance both employees and company owners can win greater profits, but when a deeper analysis is made, social and health issues can be observed. For workers, in short term, the income earned with higher levels of energy expended in production let them buy more goods that their family needs to survive. While, on the other hand, for capitalists, it is the most effective managerial strategy to intensify workers energy expended while this process reduce production costs and to reduce, in long term, the workers salary. But the relationship between these two factors is not clear as, in the first view, if the workers earn higher wages, the production costs will increase, creating an administration problem. This happens only if the wage is paid on the working journey time basis. But if it is related to worker productivity, the unity cost of each piece produced (and used as reference for the salary) may decrease, as the average production time is reduced, leading to a reduction in the final remuneration (Dal Rosso, 2008).

For sugarcane manual cutters, the production-based payment is the promise of better wages because using this HRM strategy, the worker have the impression that their salary has increased as he could raise his individual productivity, what do not happen as the unity value decrease. With this remuneration method, the sugarcane manual cutters had their average production increased by $100 \%$ from the 1990 s to the 2000 s decade (Alves, 2006) as the salary decreased in the same period (Ramos, 2009). This productivity allowed sugarcane companies to remain competitive in international market, with a social cost of many sick workers due to the work intensification process (Alves, 2006; Silva, 2013; Verçosa, 2018; Vilela et al., 2015). Therefore, the payment method is a central HRM strategy, and it is more effective when management can stablish higher control levels on workforce activities, what HR managers look for to obtain through the application of other strategies.

The recruitment and selection strategy aims to support managers, using pre-defined indicators to hire workers with a predetermined profile that may avoid discipline problems and have useful expertise for work productivity. Human resources literature points that a selective hiring is a key practice to improve organizational performance (Gerxhani \& Koster, 2015; Vlachos, 2008). This strategy is historically used in São Paulo state sugarcane AIC, mainly to choose the high qualified, but also the most vulnerable employees (Menezes et al., 2012; Novaes \& Alves, 2007), although only few researchers tried to explain which workers characteristics sugarcane HR managers are searching for in the harvest mechanization context (Scopinho et al., 1999).

Finally, the training programs can be used to qualify workers, to establish a disciplined behavior and a work quality pattern (Cover, 2011; Salata, 2013), what is a strategy to reduce workers actions that do not act positively to increase productivity. The analysis of these practices can contribute to describe the HRM strategies used do increase productivity in Brazilian sugarcane AIC agricultural production.

\section{Method}

In this study, two different methodological approaches were used. Firstly, a quantitative analysis, included the creation and application of a questionnaire (Appendix A), that provided general data from the HRM practices and was useful to 
make comparative analysis of the indicators in diverse categories. The qualitative approach was used to subsidize the results of the quantitative method, by illustrating the general analyses with concrete data from different actors of the sugarcane production. This approach is also important to verify the contradictions inherent of the work process in capitalism social structure, confronting the managers and workers speech about HRM practices and their consequences to work conditions.

The primary data was collected by applying the questionnaire to sugarcane HR managers on September 25, 2015 during the XIV Seminar of the Human Resources Research Group in Agroindustry (GERHAl), held in Sertãozinho, SP, Brazil. The questions were structured based on observations and interviews conducted the sugarcane industries, participation in meetings and events of the sector, and information collected in the literature about agricultural HRM and the HRM in the sugarcane agro-industrial complex (Souza, 2011).

A number of $38 \mathrm{HR}$ sugarcane AIC managers, from seven different São Paulo State administrative regions, answered the questionnaire, representing a large geographical area, what can strength general analyses from the entire State. The data from the questionnaires was stratified according to two management types: (A) family management companies, with the administration based on tradition, heritage, and personal relations, and $(B)$ professional management companies, which started to replace the family management companies, after the 2000 s, being based on rational assessments, meritocracy by competence, and an HRM more engaged in the company decisions (Sánchez-Marín et al., 2017; Souza, 2011). The objective of this stratification was to identify general and specific trends of HRM in the sugarcane AIC modernization process. The professional management companies were the basis of this analysis, as they generally carry out transformations followed by the others, motivated by the continuous need to reduce costs in the inter-capitalist competition. However, by identifying the characteristics of HRM in family management firms it's possible to verify the heterogeneity in the modernization process of sugarcane AIC in São Paulo.

In order to strengthen the analysis with concrete elements, qualitative information was collected in sugarcane companies with different management types using the methodological concepts of social investigation suggested by Thiollent (1982). Field observations were recorded in a diary for all the 5 case studies in different sugarcane mills. It was selected 17 actors to conduct semi-structured interviews, among them 6 agricultural managers, $5 \mathrm{HR}$ managers, 2 manual workers and 4 machine operators. All these recordings were transcribed and systematized in categories related to the HRM practices and agricultural stages of the sugarcane production. Some interviews were not recorded, as it was conducted in the field, and further notes were took to register the main data.

\section{Human Resources Management strategies}

As the recruitment and training strategies are used to create the conditions to an efficient application of the payment method to increase work productivity, it is more appropriated to explain first these two factors and then make a deep analysis of the central factor, what can help to understand the HRM strategies in São Paulo State sugarcane AIC. 


\subsection{Recruitment and selection of machine operators}

The recruitment is a HR strategy used to select workers and has a great importance to any type of business, hiring a specific labour profile, making it easier for managers to reduce costs in this process (Gerxhani \& Koster, 2015; Vlachos, 2008). Thus, in the selection process, it is necessary to define the characteristics that are required for each job position upon which managers base their decisions.

Analysing the HR managers response about this subject, the feature that comes in the first position for the agricultural machinery operators recruitment, especially for sugarcane harvesting in family-run enterprises is 'Length of experience', ranked in second place for professional management companies (Table 1). This means that the recruitment aims operators who have already worked in that function and have a tacit knowledge of machines operation. This knowledge type is essential to the production flow and rhythm, because it is the experience in the activity that give operators the necessary competences to overwhelm the inherent work variability, and to develop new technological devices (Narimoto \& Burgess-Limerick, 2015; Johnson et al., 2019).

Table 1. Recruitment and selection characteristics priority for hiring agricultural machine operators, according to management type (average).

\begin{tabular}{lccc}
\hline \multicolumn{1}{c}{ Characteristics } & $\begin{array}{c}\text { Accumulated data } \\
\text { (Average) }\end{array}$ & \multicolumn{2}{c}{$\begin{array}{c}\text { Management type } \\
\text { (Average) }\end{array}$} \\
\cline { 3 - 4 } & & Professional & Family \\
\hline Length of experience & 2.8 & $3.6(2)$ & $1.9(1)$ \\
\hline Truck driver's licence & 3.9 & $2.9(1)$ & $5.0(3)$ \\
\hline Behavioural history & 4.3 & $3.6(2)$ & $5.0(3)$ \\
\hline Training of machine operation & 4.6 & $4.3(3)$ & $5.0(3)$ \\
\hline Psychological testing & 5.5 & $6.5(5)$ & $4.4(2)$ \\
\hline Absenteeism and medical history & 6.5 & $8.0(9)$ & $5.0(3)$ \\
\hline Productivity in preceding years & 7.3 & $7.4(8)$ & $7.2(4)$ \\
\hline Maintenance training & 7.5 & $6.9(6)$ & $8.2(6)$ \\
\hline Level of education & 7.8 & $6.1(4)$ & $9.8(8)$ \\
\hline Time in the company & 8.5 & $9.0(10)$ & $8.1(5)$ \\
\hline Distance from home & 8.8 & $7.2(7)$ & $10.3(10)$ \\
\hline Wage expectation & 9.7 & $9.8(12)$ & $9.7(7)$ \\
\hline Age & 9.8 & $9.7(11)$ & $10.0(9)$ \\
\hline
\end{tabular}

Characteristics with the lowest value are the most important and the ones with the highest value are the least important for HR managers. Numbers in parentheses in columns refer to the recruitment characteristics priority order for each management type. Source: Authors.

For professional management companies, the most important characteristic in the selection process is the ownership of official authorization that enables the piloting of trucks, which takes third place for family-run companies. However, it is a legal requirement to use those kind of machines, so it is not a qualifying characteristic, but an eliminatory one for workers with less formal qualifications, such as for most sugarcane manual cutters who became unemployed by the mechanization process. Another feature relevant to this analysis is the 'Training of machine operation' prioritization, which is in third position for every company management type. This subject needs to be analysed in depth. According to Narimoto \& Burgess-Limerick (2015), some harvesting operators did not have training to operate these machines. In this sense, the interview section below shows that training is often based more on the experience the worker already has than on the formal knowledge acquired in these courses. 
Harvester Operator: For example, when you are going to learn a different activity, someone is there near you, you get a little nervous, you do things wrong. When you're alone you let it go, doing it by yourself. They gave us a short course to learn about the harvester, the instructor accompanied the group, and then he left us [alone] on the machine (verbal information).

Despite being in a lower ranking position than the 'Length of experience', the formal training is still an important characteristic, but the high number of qualification programmes for harvesting operators after the 2000s' mechanization process was responsible for training a large number of workers, providing managers with more options when it came to choose the most skilled operators. The fact that the 'Length of experience' is in the first position reinforces the hypothesis that those selected must have tacit knowledge consolidated in mechanical operations, such as the harvester. So, the short duration training is only a complement for their technical knowledge, and a behavioural preparation, as it will be discussed in the training analysis below.

Another important factor for the operator selection is discipline. The 'Behavioural history' occupies the second and the third position for professional management and family-run companies, respectively. This workers evaluation can be done by searching the database or by consulting with field supervisors for warnings and suspensions caused, for example, by poor work quality, what is observed by a regular consultation with the field manager.

Organizational Development Supervisor: We conduct two types of interviews, both at hiring and dismissal. The interview in the admission process, the recruitment, is more an interview regarding competence, to find out what skills and knowledge they has. [...] You do an almost daily follow-up. You follow-up the company's climate, you are following the return that your leader gives (verbal information).

But the worker can also be marked with bad behaviour if they had incited strikes or carried out labour lawsuits against the company - an illegal practice, but historically commonplace in the sector (Guanais, 2010).

Workers' behaviour can also be evaluated through 'Psychological testing', which helps determine a propensity for attitudes considered inadequate by HR managers. The family-run mills are the ones that value this characteristic more (2nd place). Another interesting behaviour considered by managers for sugarcane workers' recruitment is 'Absenteeism and medical history', which has high importance in family management mills (3rd place), but for professional companies it is in the 9th place, showing the first large difference between these two types of management in sugarcane AIC. The following comment, made by a training and selection analyst of a family-run mill in the central region of São Paulo state, corroborates this analysis:

Training and Selection Analyst: Now we have done a new work with health certificate that I think is fitting, reducing a little the frequency of faults. So we ask questions like requiring him to tell us a little bit about the example, what he would do, what he would not do [to avoid the fault] (verbal information).

The HRM's point of view about this kind of work absence is directly related with the employee's responsibility, blaming them for their health problems, which - probably were acquired in the work process (Alves, 2006; Gollac \& Volkoff, 1996; Scopinho et al., 1999; Vilela et al., 2015). 
The significant role of characteristics related to personal behaviour - including the fact that they consider health problems as a behaviour issue - in workers' selection demonstrates that the workforce control is essential for HR strategies. Misconduct is particularly aggravating when it comes to machine operators, whose deviations from non-compliance with certain requirements, recurring absences at work or even deliberate actions to slow down the work pace, can greatly increase production costs. Thus, through the selection of workers who possess the type of attitude that interests the company, and by the coercion based on the risk of unemployment, management practices can impose greater discipline on machine operators.

\subsection{Training and polivalence}

The machines' availability is a central factor for work productivity in sugarcane production, specifically in the harvester operation, due to its direct relation with the industry's raw material supply. Operational interruptions can occur in scheduled shutdowns, but several factors, which are usually linked to the intense use of this equipment, can lead to unexpected fails, stopping production, and affecting the industrial transformation process directly. The balance between the machines' productivity and availability is critical to reduce operating costs, because if usage becomes too intense, the breakdowns will occur more often and the time spent on maintenance will increase.

Dourado et al. (2014) identified that the machine is effectively operated for only $59.56 \%$ of the time and that $22.36 \%$ of the stops are due to unpredicted maintenance. Banchi et al. (2012) state that there is a decreasing scale in the average availability of the machines during the years of harvesting, with them being available $84.92 \%$ of the time in the first year of use and, depending on the reforms carried out in the off-season, this can decrease to $67.74 \%$ availability in the fifth year of harvesting. These authors consider that the useful life of the harvesters is over five years of operation (around 15 thousand hours); after that the use of the machine may become operationally and economically unfeasible.

To mitigate the effects of these long maintenance stops, the agricultural machine operators must be able to perform some types of repairs on the equipment to increase their availability and reduce the workers idleness. This work flexibility, a management practice that is widespread with the consolidation of the Flexible accumulation (Harvey, 1989) paradigm, requires the worker to carry out activities for which they were not hired and does not usually have tacit knowledge for this activity. Therefore, worker training is fundamental to provide them with the technical skills necessary to carry out these new tasks, and not only for that, because it is also important to train them with the most appropriate behavioural characteristics to perform this work.

In order to analyse the relationship between polyvalence and trainings programs for machine operators, we will evaluate two questions: a) What is the maintenance trainings' level of complexity and comprehensiveness provided by the companies to the machine operators? b) What are the leadership training objectives in the agricultural area? The interest here is to verify whether the maintenance task of agricultural machines and implements, as well as labour inspection, has also become a function of the machine operators, making them polyvalent and more disciplined in the interests of the company. The maintenance training is very important for the mills, since only $4 \%$ of these companies do not provide this qualification to their machine operators 
(Table 2). All the companies with professional management carry out this training and less than $10 \%$ of the family-run mills do not carry out it.

Table 2. Percentage of equipment maintenance training provided to machine operators in the São Paulo state Sugarcane AIC, according to management type.

\begin{tabular}{cccc}
\hline \multirow{2}{*}{ Training type } & \multirow{2}{*}{ Accumulated data (\%) } & \multicolumn{2}{c}{ Management type (\%) } \\
\cline { 3 - 4 } & 39 & Professional & Family \\
\hline Preventive & 26 & 36 & 43 \\
\hline Corrective & 18 & 28 & 24 \\
\hline Complete maintaining & 14 & 17 & 19 \\
\hline Mechanical assistant & 4 & 19 & 5 \\
\hline No training & 100 & 0 & 10 \\
\hline & & 100 & 100 \\
\hline
\end{tabular}

Source: Authors.

São Paulo state mills generally place great emphasis on preventive maintenance training for machine operators. This is the simplest and shortest duration type of qualification, because it, basically, involves checking the machines' condition, but it is the knowledge base for other training and maintenance activities. This type of training still does not replace the mechanic on the job front, but only allows the operator to check some critical points of the machine and perform the cleaning and some small repairs, such as lubrication of the gears or exchange according to the time of use of some specific parts.

One of the interviewees (machine operator) mentioned the existence of a 74-item checklist involving procedures for different situations when operating a harvester. Although the items in this document are based on technical instructions, it can also be used as a behaviour reference for the managers as their normativity can be used to hold workers accountable for the machine availability, justifying the judgment - and punishment - of an unexpected situation as a human error situation.

The worker trained in preventive maintenance is called a maintainer's operator. They are directly related to the equipment availability, because, for HR managers, before starting the operation, potential problems can be already identified and solved, such as loose bolts, possible leaks, among others.

Driver and Operator Instructor: In the old days, for example, the machine would be stopped; until the mechanic had finished [fixing] the base pair in the stopped harvester he could not go to the other machine to retighten and solve the problem, so there were two harvesters stopped. Now, with the maintainer's operator the situation is different. He goes there tightens [the hydraulic hose], solves the problem and goes back to work. So we have only one stop, the other one he stops for 10 minutes, tightens, and goes back to work. We save time (verbal information).

Another training programme is for auxiliary mechanics, performed by less than $19 \%$ of the companies, and less than $5 \%$ for the family management companies. This training usually takes place during the off-season, when the machines undergo a complete reform and the operators would normally be idle. In other words, they leave their function as operators and become auxiliary mechanics during the off-season, with two different advantages to the mills. Firstly, the harvester operators do not stand idle during the off-season, as they work in another function: auxiliary mechanic. In the second place, while they are learning about the 
maintenance job, their tacit knowledge about the most recurring machine failures, learned in the day-to-day operation, is used by the mechanic to make adjustments in the harvesters (Narimoto \& Burgess-Limerick, 2015).

Agricultural Logistics Coordinator: Maintenance training, and the staff would effectively assist in all-time maintenance in the off-season. Instead of them standing idle, they go there, they dismantle the machine, accompanied by our automotive instructors. They accompany our staff, they go straight to fix the machine, see all the problems that the machine has. They dismantle the machine, and go through it part by part finding the faults (verbal information).

Comparing the accumulated data of the most basic training programme (Preventive maintenance, Mechanical assistant and Not training) with the most complete ones (Corrective maintenance and Complete maintenance) one can see that the most complex type of training is realized by $44 \%$ of all mills analysed. Although not an expressive value, there is a tendency in the sugarcane AIC to replace the front mechanics with a maintenance-operator, who can perform almost all the necessary machine maintenance tasks during the working day. It should be emphasized that this training allows for a significant reduction of mechanics required for the maintenance of the agricultural machinery, since the maintenance-operator facilitates the mechanics' work, identifying and repairing many problems without their help.

The standardization of the maintenance job, coupled with a checklist and timed procedures, allows managers to monitor the performance of both the operator and the mechanic more rigorously. Goals are set for equipment availability, which are used to reward the workers - as will be discussed more fully in the section on payment - and for deciding in advance when stops are required for preventive maintenance. In addition to these management advantages, this HRM practice can be used to reduce the number of employees, increasing the amount of tasks each person must accomplish, what can contribute to intensify the work of the remaining operators.

Another factor that contributes indirectly to the work productivity is that, despite having this technical guidance, the company values and interests are also transmitted in this training. The objective is to create a behavioural pattern incorporating the company's objectives, as in the following motto presented by a Crop Front Manager interviewed:

My equipment is my sustenance, I have to take care of that machine, or of that car, as if it were mine, I must have a sense of ownership, because it is from it that comes my livelihood (verbal information).

This attempt to make workers believe that the company's objective is the same as their own can be more clearly observed when the leadership training is critically analysed, as Scopinho (2000) did for the Total Quality training programmes, or Salata (2013) did for the harvester operation qualification programme. These trainings try to access the worker subjective and cognitive aspect, restricting the contradictory strategies of resistance they can use in the production and domestic space.

In this sense, the term 'leadership' or 'leader' was used recurrently in the HR managers' interviews. It euphemistically replaces the term 'field supervisor', but it can also refer to the workers behavioural characteristics related to their discipline. However, this training programme proved to have less relevance in comparison with maintenance because of the high negation (17\%) of its existence in surveyed companies (Table 3 ). 
Table 3. Leadership training objective in the sugarcane AIC of the state of São Paulo, according to management type.

\begin{tabular}{lccc}
\hline \multirow{2}{*}{ Leadership training objective } & \multirow{2}{*}{ Accumulated Data (\%) } & \multicolumn{2}{c}{ Management type (\%) } \\
\cline { 3 - 4 } & & Professional & Family \\
\hline Establish behavioural pattern & 39 & 41 & 37 \\
\hline Strengthen hierarchy & 27 & 27 & 26 \\
\hline No training & 17 & 23 & 11 \\
\hline Allow operation and leadership & 17 & 9 & 26 \\
\hline Reduce inspectors & 0 & 0 & 0 \\
\hline
\end{tabular}

Source: Authors.

Even so, the establishment of a behavioural pattern among employees was held to be of high importance among the companies, being $39 \%$ of the total respondents and $41 \%$ for professional management companies. Therefore, the need to align employees with the behaviour that they consider appropriate using this kind of training is a strong objective among sugarcane company HR managers in São Paulo. That is, leadership training plays a significant role in increasing managerial control over employees, bringing them closer to the organization's interests. While the workforce control is subtly inserted within those trainings programmes, the payment mechanism makes it clear that the intention of the companies' HRM is to increase productivity through work intensification.

\subsection{Payment types for machine operators}

The payment method used in the São Paulo state sugarcane AIC can vary with the different agricultural activities and companies managerial types, but the predominant payment form for machine operation is the variable remuneration. Its major characteristic is that the remuneration has two portions: a fixed one, related to the basic salary of the category, and another one that varies according to objective indicators chosen by the companies managers.

CCT Supervisor: The normal salary today - let's talk about operators and drivers - so we are talking about $70 \%$ fixed, and the other $30 \%$ we work with variable [salary]. This variable part will be linked to productivity, availability of the operator's equipment, efficiency and consumption. So each group of... or truck, harvester, tractor, has its bonus differentiated according to what the operator does. The harvesters, for example, enters how much cane they are leaving behind, how much soil they are bringing to the industry. So with the combination of all that, they can achieve there, up to 700 real $(R \$)$ in bonus (verbal information).

The managers consider the possibility of the employees to earn up to $30 \%$ above the fixed remuneration, but only if they reach the established productivity goal. To obtain this 'prize', the workers are evaluated by parameters that involve the quality of their work, and their discipline. This means that despite the goal evaluation, operators will only effectively receive this award if there are no discounts as punishment for an inadequate behaviour using the machine, or having substandard sugarcane produced, or even by his absenteeism. This management logic, based on prizes and punishments, is an old element of the São Paulo state sugarcane AIC, as described by 
many authors that studied organizational factors of manual cutters activity (Alves, 2006; Souza, 2011).

The indicators used for calculating the operators' payment are efficiency (Labour productivity and Overcoming production goals), non-compliance with the requirement (Stops and equipment breakdown, Cane losses, Diesel expenses, Straw excess) and indiscipline (Absenteeism, Medical certificate and Others - Errors of note and Managers' Warnings) (Table 4). The indicators related with efficiency are used to reward the machine operator if they have a good productivity, and the other two types do not necessarily increase their wage, but can reduce it if they are not meeting the minimum level.

Table 4. Percentage of payment calculation criteria used in machine operators' wage in sugarcane AIC of the São Paulo state, according to management type.

\begin{tabular}{lccc}
\hline \multirow{2}{*}{ Payment criteria } & $\begin{array}{c}\text { Accumulated Data } \\
\mathbf{( \% )}\end{array}$ & \multicolumn{2}{c}{$\begin{array}{c}\text { Management type } \\
\text { (\%) }\end{array}$} \\
\cline { 3 - 4 } & 26 & 26 & Family \\
\hline Labour productivity & 15 & 16 & 26 \\
\hline Absenteeism & 14 & 16 & 12 \\
\hline Overcoming production goals & 11 & 10 & 12 \\
\hline Stops and equipment breakdowns & 10 & 11 & 15 \\
\hline Cane losses & 8 & 10 & 6 \\
\hline Diesel expenses & 7 & 5 & 6 \\
\hline Medical certificate & 7 & 5 & 12 \\
\hline Straw excess & 4 & 2 & 3 \\
\hline Others & 100 & 100 & 100 \\
\hline
\end{tabular}

Source: Authors.

The importance given to reward and punishment criteria differ with the company type, but one characteristic is undoubtedly a priority for all types of company: 'Labour productivity' (Table 4). This is the major indicator for the wage calculation in any company, accounting for $26 \%$ of the answers for all of them. The sum of 'Labour productivity' and 'Overcoming production goals' corresponds to $40 \%$ of all variable remuneration criteria for any type of management, being $42 \%$ for professional companies and $38 \%$ for the family-run ones. 'Absenteeism', a punishment criterion, has the same importance as 'Overcoming production goals' $\left(2^{\text {nd }}\right.$ place $)$ for both management types.

The high value of absenteeism in the payment calculation can be explained by the individual importance of each worker in mechanized sugarcane production. By using new technologies and advanced management practices, the number of employees on the work front is reduced. The absenteeism of one worker on the harvesting front, for example, can cause serious problems to the industry supply chain, or, at least, it obligates managers to make changes to the planned work coordination with production losses. This relationship between reliability of the system and the number of employees can explain why managers in all types of mills try hard to control absenteeism by punishing it through the payment calculation.

'Cane losses' is also a relevant criterion for the remuneration punishment, being more important for the professional management mills. This charge always existed even in the manual sugarcane harvest, and field managers used to inhibit it with the use of the 'hook' (suspension from work for a few days) to punish deviations in the 
prescription of the task, such as cane losses, or any behaviour considered inappropriate by the supervisors (Guanais, 2016). Currently, mechanized sugarcane harvest predominates (Fredo et al., 2015), and the workers' punishment has become more modern - and subtle - with the use of variable remuneration.

'Stops and equipment breakdowns' and 'Diesel expenses' are directly related to the costs of mechanization (Ahmed \& Alam-Eldin, 2013). This data are produced with the new technologies used in harvesters, as the on-board-computer, with a major objective to surveille workers activity and to measure their work quality, showing that this control logic has not been overcome with this modernization process. Thus, the wage punishment based on this element not only restricts this type of resources waste, but it also lets the companies share the cost of equipment breakdown with the workers as it is charged on salary. Family-run companies value 'Stops and equipment breakdowns' more than the professional management ones, what can be explained by their smaller capital availability as they cannot afford all the required structural changes in sugarcane plantation, machines and operator control technologies as easily as the more capitalized companies (Table 4). The professional management firms use more technical and organizational innovations in the agricultural work process and have a more efficient preventive maintenance programme, reducing equipment from stopping and breaking down. Thus, fuel consumption should be more relevant for some companies, especially those that still have areas without adequate terrain systematization for mechanical operations, requiring a greater number of machines manoeuvers.

By analysing the criteria of punishment related to the quality of work (Stops and equipment breakdowns, Cane losses, Diesel expenses and Straw excess), and those related to workforce control (Absenteeism, Medical certificate, Other), it is possible to evaluate the companies' heterogeneity in variable portion terms that influences machine operators' wages (Table 4). The accumulated data indicate that modern companies (professional management) are more concerned with work quality $(36 \%)$ than with workforce control $(23 \%)$. This may be related to technological innovations used with the harvesters, which are more efficient in workforce control, but do not guarantee its quality, which is still closely linked to the experience of operators. Family-run companies, which have more difficulty in modernizing themselves, do not distinguish between these two types of punishment, endeavoring to decrease costs in order to maintain the competitiveness.

Accumulating the criteria data used as incentives (Productivity, Overcome production targets) and the ones used for punishment in the calculation of workers' compensation (Absenteeism, Stops and equipment breakdown, Cane losses, Diesel expenses, Medical certificate, Straw excess, Other), management differences between companies can be identified. The professional management companies use $58 \%$ of the criteria related to the punishment and control of workers, whereas the family-run companies use punishment in $62 \%$ of the cases. Even with relatively small differences when comparing bonuses and punishment criteria as a whole, the differences between the management types are greater when the components of these criteria are considered in isolation.

The overall results of this study are in agreement with studies on HRM for the industrial and service companies, showing differences between professional and family companies, in terms of recruitment, training and compensation strategies (Kotey \& Folker, 2007; Sánchez-Marín et al., 2017). In the agricultural sector, the findings also support the importance of these three HRM practices. As pointed out by Bitsch et al. (2006), it is important to hire skilled labour. In their research, farmers included the lack 
of skilled labour as the top 10 risks in dairy farm management. The authors suggested increasing labour abilities through training and developing compensation strategies to keep the employee in the job, which can also be done through payment rewards by meritocracy, like companies do in sugarcane AIC. To replace a trained (experienced) employee is highly costly (Mugera \& Bitsch, 2005) and, in a small work market, such as that of skilled operators, the manager needs to use strategies to maintain the employee in the job while guarding the company's interests (Bula 2012). By applying these kinds of HRM strategies, managers can increase productivity using the workers tacit knowledge and motivating them to increase productivity by intensifying their work, an old workforce management practice in the sugarcane sector, but with a new modernized surface.

\section{Conclusions}

The technological innovations implemented in agriculture allow the capitalist to increase productivity, which is potentialized by HRM strategies focused on work intensification and control. In the specific São Paulo State sugarcane AIC case, management changes have a direct relationship with the harvesting mechanization process implemented in the last decades.

The main HR managers strategy in this sector is the variable remuneration, a payment method based on productivity used to encourage machine operators to intensify their own rhythm of work, what may be done by the expend of more physical and mental energy. This strategy is conditioned on manager capacity to control the workforce, which makes it possible to use workers' tacit knowledge in the production process to maintain quality and to establish a behaviour pattern aligned to the companies' interests. This control can be obtained through different ways: with a specific worker profile selection, by training workers to adopt the required behaviour, and by punishing them with a reduction in their wages when they do not follow established procedure. This control allows managers to be more effective when implementing strategies that increase productivity at work, such as the multipolivalence created by the operators-maintainers, and the wage incentive in the payment based on production.

Although the same indicators are the basis for managerial decision-making in the analysed companies, the heterogeneity of the modernization process in São Paulo sugarcane AIC is evident. As a function of the industry's type of management, different priorities are given to these characteristics, showing an organizational structure that combines old and new managerial practices due to its different modernization stages. Thus, the changes brought by the modernization process in this agricultural HRM practices are superficial, as the prize and punishment logic is still the central element of workforce management, a historically administration rationality in this sector. They only reproduce old mechanisms of exploitation, such as payment for production, now euphemistically called 'variable remuneration'. The great element to support this affirmation is the fact that the new technologies associated to the machine operation are mainly used to workers surveillance and to measure indicators used as prize or punishment in the variable remuneration.

This study main conclusion is that the work intensification are still an issue in sugarcane agro-industrial complex, because it is central for productivity and, consequently, for the companies profitability, but the specialized literature points as the major illness factor for the workers, indicating a contradictory relation between the 
worker and companies interests. The consequences of this intensification process for machine operators health must be analyzed with greater depth, what can be done by using different scientific methods.

The ergonomic activity analysis can reveal details of the work process that only the operators tacit knowledge can provide, showing the specific moments when the intensification process reduce the space of action to protect their own health. The occupational exposure analyzes to heat, vibration, noise and chemical risks exposure can also be measured, contributing to the ergonomic activity analysis with quantitative elements to strength its qualitative approach. The physiological and psychological stress analysis can indicate if there are any changes in the workers organism, especially during the harvesting season, which may affect their health.

\section{References}

Aguiar, D. A., Rudorff, B. F. T., Silva, W. F., Adami, M., \& Mello, M. P. (2011). Remote sensing images in support of environmental protocol: monitoring the sugarcane harvest in São Paulo State, Brazil. Remote Sensing, 3(12), 2682-2703. http://dx.doi.org/10.3390/rs3122682.

Ahmed, A. E., \& Alam-Eldin, A. O. M. (2013). An assessment of mechanical vs manual harvesting of the sugarcane in Sudan: the case of Sennar Sugar Factory. Journal of the Saudi Society of Agricultural Sciences, 14(2), 160-166. http://dx.doi.org/10.1016/j.jssas.2013.10.005.

Alves, F. (2006). Porque morrem os cortadores de cana. Saúde e Sociedade, 15(3), 90-98. http://dx.doi.org/10.1590/S0104-12902006000300008.

Baccarin, J. G. (2017). Uso dos dados do censo agropecuário no estudo dos efeitos da expansão canavieira sobre a estrutura agrária do Estado de São Paulo, Brasil. Cadernos CERU, 28(1), 11-32. Retrieved in 2016, December 5, from http://www.periodicos.usp.br/ceru/article/view/137113

Banchi, A. D., Lopes, J. R., Ferreira, V. A. C., \& Scaranello, L. T. (2012). Análise de reforma de colhedoras de cana-de-açúcar. Revista Agrimotor, 8(75), 40-43.

Bitsch, V., Kassa, G. A., Harsh, S. B., \& Mugera, A. W. (2006). Human resource management risks: sources and control strategies based on dairy farmer Focus Groups. Journal of Agricultural and Applied Economics, 38(1), 123-136. http://dx.doi.org/10.1017/S1074070800022112.

Bula, H. O. (2012). Labor turnover in the sugar industry in Kenya. European Journal of Business and Management, 4(9), 111-119.

Cover, M. O. (2011). "Tranco da Roça" e "A Vida no Barraco": um estudo sobre trabalhadores migrantes em setor do agronegócio canavieiro (Dissertação de mestrado). Centro de Humanidades, Universidade Federal de Campina Grande, Campina Grande.

Dal Rosso, S. (2008). Mais trabalho! A intensificação do labor na sociedade contemporânea (206 p.). São Paulo: Boitempo.

Dejours, C. (2005). O fator humano (M. I. S. B. Betio \& M. J. Tonelli, Trad., 5. ed., 104 p.).Rio de Janeiro: Editora FGV.

Dourado, T. H., Cassia, M. T., Compagnon, A. M., Silva, R. P., \& Catasse, M. G. (2014). Colheita mecanizada de cana-de-açúcar monitorada por meio de computador de bordo. In Anais do XLII Congresso Brasileiro de Engenharia Agrícola. Campo Grande: SBEA. Retrieved in 2016, December 5, from http://www.sbea.org.br/conbea/2014/anais/R00881.pdf

Fredo, C. E., Caser, V. D., Sachs, R. C., Olivette, M. P. A., \& Veiga, A. A., Fo. (2015). Mecanização na colheita da cana-de-açúcar paulista supera 80\% na safra 2012/13. 
Análises e Indicadores do Agronegócio, 10(2), 1-5. Retrieved in 2016, December 5, from http://www.iea.sp.gov.br/ftpiea/AIA/AIA-12-2015.pdf

Gerxhani, K., \& Koster, F. (2015). Making the right move. Investigating employers' recruitment strategies. Personnel Review, 44(5), 781-800. http://dx.doi.org/10.1108/PR-12-2013-0229.

Goldemberg, J. (2007). Ethanol for a sustainable energy future. Science, 315(5813), 808-810. http://dx.doi.org/10.1126/science.1137013. PMid:17289989.

Gollac, M., \& Volkoff, S. (1996). Citius, altius, fortius. L'intensification du travail. Actes de la Recherche en Sciences Sociales, 114(1), 54-67. http://dx.doi.org/10.3406/arss.1996.3194.

Guanais, J. B. (2010). O mundo do trabalho da agroindústria canavieira: reestruturação produtiva e seus reflexos sobre os cortadores de cana. In E. A. S. Lourenço, I. F. Bertani, J. F. S. Silva, R. S. Sant'Ana \& V. L. Navarro (Eds.), Trabalho, saúde e serviço social (1. ed., pp. 283-293). Curitiba: CRV.

Guanais, J. B. (2016). Pagamento por produção, intensificação do trabalho e superexploração na agroindústria canavieira brasileira (Tese de Doutorado) - Instituto de Filosofia e Ciências Humanas, Universidade de Campinas, Campinas.

Harvey, D. (1989). The condition of postmodernity: an enquiry into the origins of cultural change (378 p.). Cambridge: Blackwell Publishers.

Johnson, T. L., Fletcher, S. R., Baker, W., \& Charles, R. L. (2019). How and why we need to capture tacit knowledge in manufacturing: case studies of visual inspection. Applied Ergonomics, 74, 1-9. http://dx.doi.org/10.1016/j.apergo.2018.07.016.

Kotey, B., \& Folker, C. (2007). Employee training in SMEs: effect of size and firm type-family and nonfamily. Journal of Small Business Management, 45(2), 214-238. http://dx.doi.org/10.1111/j.1540-627X.2007.00210.x.

Menezes, M. A., Silva, M. S., \& Cover, M. (2012). Migrant workers in Sugarcen Mills: a study of social networks and recruitment intermediaries in Brazil. Agrarian South: The Journal of Political Economy, 1(2), 161-180. http://dx.doi.org/10.1177/227797601200100202.

Moraes, M. A. F. D., Oliveira, F. C. R., \& Diaz-Chavez, R. A. (2015). Socio-economic impacts of brazilian sugarcane industry. Environmental Development, 16, 31-43. http://dx.doi.org/10.1016/j.envdev.2015.06.010.

Mugera, W., \& Bitsch, V. (2005). Managing labor on dairy farms: A Resource-Based perspective with evidence from case studies. The International Food and Agribusiness Management Review, 8(3), 79-98.

Mundo, M., No. (2013). As concepções de controle em diferentes momentos da indústria sucroalcooleira: uma análise das transformações recentes a partir de uma perspectiva histórica. In M. C. Jardim (Ed.), Estado e mercado no Brasil contemporâneo: a produção de sentidos, a produção de alianças (163 p.). São Paulo: Cultura Acadêmica.

Narendra, G. K., \& Bhor, J. R. (2014). E-HRM in Indian sugar industry: differentiating tool in competitive market. IBMRD's. Journal of Management Research, 3, 190-209.

Narimoto, L. R., \& Burgess-Limerick, R. (2015). Sugar-cane harvesting machine design 'in the field'. In Proceedings of the 19th Triennial Congress of the International Ergonomics Association. Melbourne: International Ergonomics Association.

Novaes, R., \& Alves, F. (2007). Migrantes: trabalho e trabalhadores no complexo agroindustrial canavieiro (os heróis do agronegócio brasileiro) (314 p.). São Carlos: EdUFSCar.

Pitta, F. T., \& Mendonça, M. L. (2010). O etanol e a reprodução do capital em crise. Agrária, (13), 4-33. http://dx.doi.org/10.11606/issn.1808-1150.v0i13p4-33.

Ramos, P. (2009). O trabalho na lavoura canavieira paulista: evolução recente, situação atual e perspectivas. In C. Miranda \& B. Tibúrcio (Eds.), Emprego e trabalho na agricultura brasileira (Vol. 9, pp. 304-325). Brasília: IICA.

Ramos, P. (2011). Financiamentos subsidiados e dívidas de usineiros no brasil: uma história secular e ... atual? História Econômica \& História de Empresas, 14(2), 7-32. 
Reis, L. F. (2017). Modernização da produção agrícola no complexo agroindustrial canavieiro paulista e seus efeitos sobre as condições de trabalho (Tese de doutorado). Programa de Pós-graduação em Engenharia de Produção, Universidade Federal de São Carlos, São Carlos.

Reis, L. F., \& Alves, F. (2015). O novo modelo de modernização do CAI Canavieiro paulista: a velha combinação entre o arcaico e o moderno. Revista da $A B E T, 13,1$. Retrieved in 2016, December 5, from http://periodicos.ufpb.br/index.php/abet/article/view/24862/13622

Salata, R. (2013). Novas formas de organização da produção canavieira na região de Ribeirão Preto/SP: qualificação profissional e o "programa renovação" (Dissertação de mestrado). Faculdade de Ciências e Letras, Universidade Estadual Paulista "Júlio de Mesquita Filho", Araraquara.

Sánchez-Marín, G., Meroño-Cerdán, A. L., \& Carrasco-Hernández, A. J. (2017). Formalized HR practices and firm performance: an empirical comparison of family and non-family firms. International Journal of Human Resource Management. http://dx.doi.org/10.1080/09585192.2017.1289547.

Scopinho, R. A. (2000). Qualidade total, saúde e trabalho: uma análise em empresas sucroalcooleiras paulistas. RAC, 4(1), 93-112. http://dx.doi.org/10.1590/S141565552000000100006.

Scopinho, R. A., Eid, F., Vian, C. E. F., \& Silva, P. R. C. (1999). Novas tecnologias e saúde no trabalho: a mecanização do corte da cana-de-açúcar. Cadernos de Saúde Pública, 15(1), 147-161. http://dx.doi.org/10.1590/S0102-311X1999000100015. PMid:10203455.

Silva, J. E. A. R., Alves, M. R. P. A., \& Costa, M. A. B. (2011). Planejamento de turnos de trabalho: uma abordagem no setor sucroalcooleiro com uso de simulação discreta. Gestão \& Produção, 18(1), 73-90. http://dx.doi.org/10.1590/S0104-530X2011000100006.

Silva, M. A. M. (2013). Sabe o que é ficar borrado no eito da cana? Estudos Sociedade e Agricultura, 21(2), 359-391.

Silva, M. A. M., Bueno, J. D., \& Melo, B. M. (2014). Quando a máquina "desfila", os corpos silenciam: a tecnologia e degradação do trabalho nos canaviais paulistas. Contemporanea, 4(1), 85-115. Retrieved in 2016, December 5, from http://www.contemporanea.ufscar.br/index.php/contemporanea/article/view/194/98

Silva, M. A. M., \& Martins, R. C. (2010). A degradação social do trabalho e da natureza no contexto da monocultura canavieira paulista. Sociologias, 12(24), 196-240. http://dx.doi.org/10.1590/S1517-45222010000200008.

Souza, M. Z. A. (2011). Modernização sem mudanças: da contagem de cabeças à gestão estratégica de pessoas (Tese de doutorado). Programa de Pós-graduação em Engenharia de Produção, Universidade Federal de São Carlos, São Carlos.

Thiollent, M. (1982). Crítica metodológica, investigação social e enquete operária (270p.). São Paulo: Polis.

Verçosa, L. V. (2018). Os homens-cangurus dos canaviais alagoanos: um estudo sobre trabalho e saúde (316 p.). Maceió: EDUFAL.

Vilela, R. A. G., Laat, E. F., Luz, V. G., Silva, A. J. N., \& Takahashi, M. A. C. (2015). Pressão por produção e produção de riscos: a "maratona" perigosa do corte manual da cana-deaçúcar. Revista Brasileira de Saúde Ocupacional, 40(131), 30-48. http://dx.doi.org/10.1590/0303-7657000075413.

Vlachos, I. (2008). The effect of human resource practices on organizational performance: evidence from Greece. International Journal of Human Resource Management, 19(1), 7497. http://dx.doi.org/10.1080/09585190701763933. 


\section{Appendix A. Questionnaire for sugarcane RH Managers.}

\section{Questionário}

Perfil da Gestão de Recursos Humanos no Setor Sucroenergético

Este questionário faz parte da pesquisa de doutoramento em Engenharia de Produção na UFSCar. Ela é realizada pelo pesquisador Leonardo Ferreira Reis, sob orientação do Professor Doutor Francisco Alves. O objetivo desta pesquisa é entender as medidas adotadas pela gerência das empresas visando aumento da competitividade do Setor Sucroenergético. As informações provenientes deste questionário são sigilosas, e têm por finalidade a produção e divulgação de conhecimento científico sobre a gestão do setor sucroenergético.

Nome*:

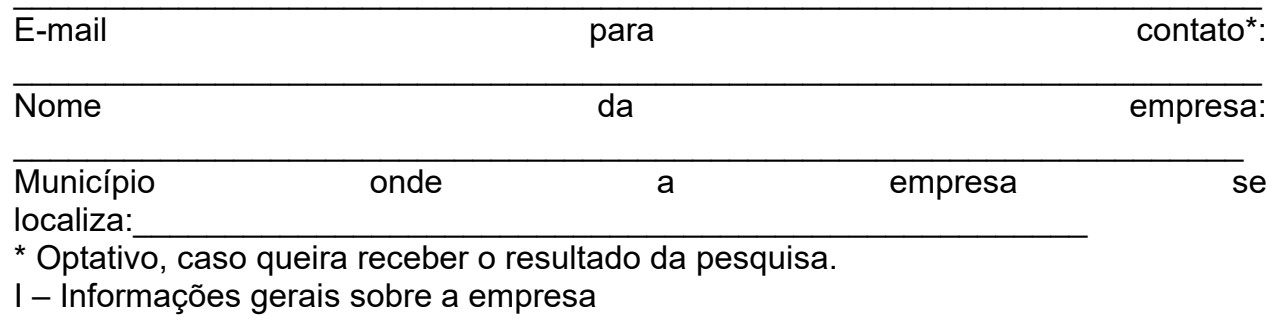

\section{Número de colaboradores na produção agrícola:}

a) Safra:

b) Entressafra:

2. Qual a forma de gestão da empresa?

\begin{tabular}{ll}
\hline ( ) Gestão Familiar & ( ) Outro. Qual? \\
\hline ( ) Gestão Profissional & \\
\hline
\end{tabular}

3. Houve fusão com outras empresas, ou aquisição/construção de novas unidades industriais nos últimos 10 anos?

( ) Sim ( ) Não

4. Qual a posição da Gestão de RH no organograma da empresa?

( ) Diretoria independente

( ) Órgão da Presidência/CEO

( ) Subordinada a outra diretoria. Qual?

II - Informações sobre Cargos e Salários dos colaboradores da produção agrícola

5. Qual tipo de programa de remuneração dos colaboradores da produção agrícola considerando manuais e operadores de máquinas? (pode ser assinalada mais de uma opção)

\begin{tabular}{ll}
\hline ( ) Pagamento por produção & ( ) Salário por horas trabalhadas \\
\hline ( ) Salário fixo + parcela variável & ( ) Outro. Qual? \\
\hline
\end{tabular}

6. Quais são os critérios utilizados no cálculo da parcela variável? (pode ser assinalada mais de uma opção)

\begin{tabular}{ll}
\hline ( ) Superar metas de produção & ( ) Paradas e quebra do equipamento \\
\hline ( ) Absenteísmo & ( ) Excesso de palha \\
\hline ( ) Perdas de cana & ( ) Atestado médico \\
\hline ( ) Gastos de diesel & ( ) Histórico de rendimento \\
\hline ( ) Produtividade & ( ) Outros. Quais? \\
\hline
\end{tabular}


7. Como as metas de produção de cana são estabelecidas? (pode ser assinalada mais de uma opção)

\begin{tabular}{ll}
$\begin{array}{l}\text { ( ) São fixadas pela produção/dia na safra } \\
\text { anterior }\end{array}$ & $\begin{array}{l}\text { ( ) Variam com produtividade do talhão } \\
\text { (ton/ha ou pol/ha) }\end{array}$ \\
\hline $\begin{array}{ll}\text { ( ) Variam com a produtividade do trabalho } \\
\text { indiv. }\end{array}$ & $\begin{array}{l}\text { ( ) Variam com a idade das máquinas nas } \\
\text { frentes }\end{array}$ \\
\hline $\begin{array}{l}\text { ( ) Variam com a produtividade do trabalho } \\
\text { equip. }\end{array}$ & $\begin{array}{l}\text { ( ) Outros. } \\
\text { Quais? }\end{array}$ \\
\hline
\end{tabular}

III. Informações sobre Treinamento dos colaboradores da produção agrícola

8. O treinamento dos operadores de máquinas os qualificam para qual tipo de manutenção? (pode ser assinalada mais de uma opção)

( ) Operadores não recebem esse treinamento

( ) Auxiliar do mecânico

\begin{tabular}{ll}
\hline $\begin{array}{l}\text { ( ) Manutenção preventiva durante a } \\
\text { jornada }\end{array}$ & $\begin{array}{l}\text { ( ) Manutenção completa da máquina } \\
\text { (safra/entressafra) }\end{array}$ \\
$\begin{array}{ll}\text { ( ) Manutenção corretiva durante a } \\
\text { jornada }\end{array}$ & ( ) Outra. Qual? \\
\hline
\end{tabular}

9. Quais as principais vantagens do treinamento de lideranças? (pode ser assinalada mais de uma opção)

\begin{tabular}{ll}
$\begin{array}{ll}\text { ( ) Colaboradores não recebem esse } \\
\text { treinamento }\end{array}$ & ( ) Estabelece padrão comportamental \\
\hline ( ) Fortalece a hierarquia & $\begin{array}{l}\text { ( ) Permite que operadores exerçam função de } \\
\text { liderança }\end{array}$ \\
\hline ( ) Diminui a necessidade de fiscais & ( ) Outra. Qual?
\end{tabular}

IV - Informações sobre Recrutamento e Seleção na produção agrícola

10. Qual a prioridade dada às seguintes características individuais no momento da contratação de colaboradores para ATIVIDADES MANUAIS AGRÍCOLAS? (Sugere-se que todas as opções sejam lidas antes de classifica-las)

\begin{tabular}{ll}
\hline \multicolumn{1}{c}{ Característica } & Ordem de Prioridade \\
\hline Escolaridade & \\
\hline Histórico de absenteísmo e atestados & Histórico comportamental \\
\hline Experiência nessa atividade \\
\hline Produtividade em outras safras \\
Origem do colaborador - migrante \\
Origem do colaborador - local \\
\hline Tempo na empresa \\
\hline Resposta a testes psicológicos \\
\hline Idade \\
\hline Outra. Qual?
\end{tabular}

11. Qual a prioridade dada às seguintes características individuais no momento da contratação para a OPERAÇÃO DE MÁQUINAS AGRÍCOLAS? (Sugere-se que todas as opções sejam lidas antes de classifica-las)

\begin{tabular}{ll}
\multicolumn{1}{c}{ Característica } & Ordem de Prioridade \\
\hline Resposta a testes psicológicos & \\
\hline Histórico de absenteísmo e atestados & \\
\hline Histórico comportamental & \\
\hline Tempo de experiência & \\
\hline Produtividade em outras safras
\end{tabular}




\section{Característica}

Ordem de Prioridade

Curso de operação de máquinas

$\mathrm{CNH}$ especifica para caminhão

Idade

Treinamento em manutenção preventiva

Distância da moradia em relação à unidade industrial

Tempo na empresa

Expectativa de remuneração

Escolaridade

Outra. Qual? 